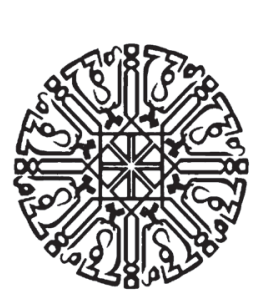

\title{
Transformasi Nilai-Nilai Islam dalam Hukum Positif
}

\author{
Yogi Prasetyo \\ Universitas Muhammadiyah Ponorogo \\ yogiprasetyomadiun@gmail.com
}

\begin{abstract}
This article aims to explain the problem of national positive law which dried up religious values and efforts to transform Islamic values into national positive law. The research method used is socciological jurisprudence which studies law as behavior related to positive legal norm systems. The results showed that Indonesian law used a civil law system inherited from the Dutch colonizers who understood the law as a form of written legislation that was not related to life values, including religion. Dictotomic law is separate from religion. The impact of the law becomes secular, only related to worldly matters, so breaking the law is not a sin. Therefore it is necessary to transform Islamic values into positive national law so that law is understood as part of obedience to God. Obeying the law also means a form of worship. Transforming Islamic values is to use values in Islam that are considered good, important and beneficial. Transformation results in the integration of law and religion into a single legal system that is formed from the legal authenticity of Indonesian people who are predominantly Muslim. This means the same as building an Islamic civilization without establishing an Islamic state
\end{abstract}

Keywords: transformation, Islamic values, positive law, Indonesia

\begin{abstract}
Abstrak
Artikel ini bertujuan untuk menjelaskan permasalahan hukum positif nasional yang kering nilai-nilai agama dan upaya melakukan transformasi nilai-nilai Islam ke dalam hukum positif nasional. Metode penelitian yang digunakan adalah sosciological jurisprudence yang mengkaji hukum sebagai perilaku yang terkait dengan sistem norma hukum positif. Hasil penelitian menunjukkan, bahwa hukum Indonesia menggunakan civil law system warisan penjajah Belanda yang memahami hukum sebagai bentuk peraturan perundangundangan tertulis yang tidak terkait dengan nilai-nilai kehidupan, termasuk agama. Hukum terdikotomik terpisah dari agama. Dampaknya hukum menjadisekuler, hanya terkait dengan urusan keduniawian, sehingga melanggar hukum bukan merupakan dosa. Oleh karena itu perlu mentransformasikan nilai-nilai Islam ke dalam hukum positif nasional agar hukum
\end{abstract}


dipahami sebagai bagian dari ketaatan kepada Tuhan. Mentaati hukum berarti juga bentuk dari ibadah. Mentransformasikan nilai-nilai Islam adalah menggunakan nilai-nilai dalam Islam yang dianggap baik, penting dan bermanfaat. Transformasi menghasilkan integrasi hukum dan agama ke dalam satu kesatuan sistem hukum yang terbentuk dari otentitas hukum masyarakat Indonesia yang mayoritas beragama Islam. Hal ini berarti sama dengan membangun peradaban Islam tanpa mendirikan negara Islam.

Kata kunci: transformasi, nilai Islam, hukum positif, Indonesia

\section{Pendahuluan}

Indonesia berdasarkan konstitusi UUD 1945 Pasal 1 ayat (3) merupakan negara hukum, artinya adalah bahwa segala kehidupan yang ada di negara ini harus dilaksanakan berdasarkan hukum. Prinsip ketatanegaraan ini telah menjadi kesepakatan bersama dari seluruh rakyat Indonesia yang diyakini mampu untuk menjamin tetap berjalannya kehidupan berbangsa dan bernegara dengan baik. Penguasa negara dan rakyat memiliki hak dan kewajiban masing-masing sesuai dengan aturan hukum yang berlaku. Hukum telah merumuskan ketentuan-ketentuannya dalam bentuk peraturan perundang-undangan yang harus ditaati semua subjek hukum yang ada di negara ini tanpa kecuali. Peraturan perundang-undangan sebagai hukum positif telah dibentuk di Indonesia dari tingkat pusat hingga tingkat daerah. Bahkan hampir seluruh kebijakan dari pemerintah telah dirumuskan dalam peraturan perundang-undangan. Maka tidak heran jika negara Indonesia dijuluki oleh negara lain sebagai laboratorium peraturan perundang-undangan, karena segala peraturan perundang-undangan ada di Indonesia. Akan tetapi apakah dengan banyaknya peraturan perundang-undangan tersebut menjadikan hukum di Indonesia lebih baik atau sebaliknya. Hukum yang seharusnya digunakan untuk memberikan perlindungan kepada masyarakat, justru dirasakan sebagai alat untuk menindas masyarakat. Hukum tidak mampu memberikan rasa keadilan, karena masih banyak masyarakat yang merasakan dampak ketidak adilan dari hukum.

Banyaknya peraturan perundang-undangan yang dibentuk negara ternyata belum mampu memberikan perubahan yang subtantif dari permasalahan hukum. Meskipun secara formal hukum mampu menjalankan tugasnya sebagai peraturan yang sah untuk mengatur kehidupan bernegara, akan tetapi hal itu hanya berjalan pada tataran luar. Artinya hukum hanya sebagai perangkat yang bertugas untuk mencapai tujuan peraturan perundang-undangan, yaitu kepastian hukum. Hukum belum mampu menyentuh aspek moral spiritual dari subjek hukum. Hal itu dapat dilihat dari bagaimana hukum tata negara Indonesia yang masih berpihak pada kepentingan elit penguasa, seperti perlakuan yang lebih/istimewa dan gaji yang tinggi disaat negara sedang menahan beban hutang luar negeri yang sangat besar. Dalam hukum pidana belum dilindunginya hak-hak korban, karena

al-ạ̣kām Vol. 5, Nomor 1, 2020 
aparat penegak hukum lebih mengutamakan penegakan peraturan perundang-undangan daripada kepentingan korban. Seperti memenjarakan terdakwa pelaku pemerkosaan, tanpa melakukan rehabilitasi dan ganti rugi kepada korban. Sedangkan di bidang hukum perdata lebih mengutamakan asas kebebasan berkontrak dan kepentingan materialistis yang dapat di wujudkan dalam bentuk uang, sehingga berdampak pada tumbuh suburnya paham liberal kapitalistik di Indonesia. Belum lagi hukum-hukum yang secara spesifik mengatur urusan tertentu yang dirasa jauh dari hakikat hukum yang sebenarnya. Seperti kebijakan di bidang pendidikan nasional yang hanya berorientasi pada ilmu pengetahuan dan teknologi, sehingga sumberdaya manusia Indonesia hanya cerdas secara logika rasional, tetapi tidak memiliki karakter mentalitas yang bermoral dan berakhlak mulai.(Tanzeh 2019, 6)

Hukum di Indonesia tampaknya telah terpisah dari aspek spiritualitas agamanya, karena lebih mengutamakan beban tanggungjawab di dunia. Sedangkan aspek-aspek dosa atau balasan setelah mati tidak dianggap sebagai urusan yang masih ada keterkaitannya dengan hukum. Maka tidak mengherankan jika walaupun mayoritas masyarakat Indonesia beragama Islam, tetapi dimensi religius dalam hukum tidak ada. Nilai-nilai Islam seperti ketuhanan, kemanusiaan, keadilan dan moralitas bukan lagi sebagai bagian dari pemahamahan hukum yang menyatu terintegrasi dengan agama, tetapi telah berbeda dan terpisah. Jika seseorang sudah tidak lagi takut akan dosa dan pembalasan di hari setelah mati, karena tidak diatur dalam peraturan perundang-undangan, maka hukum terasa hampa dan tidak bermakna. Sanksi hukum positif dinilai lebih jelas dan pasti daripada sanksi agama, karena dapat dirasakan secara nyata dalam bentuk penjara, sedangkan sanksi agama harus menunggu sampai seseorang mati untuk diadili oleh Tuhan di akherat. Hukum dipahami hanya terkait dengan urusan dunia saja atau lebih sempit lagi hukum dibatasi hanya terkait dengan urusan negara. Jika hukum hanya dipahami secara dikotomik seperti ini, maka hukum di Indonesia mengalami kehilangan ruh. Padahal ruh dalam hukum sebagai inti dari penyebab gerak dari seluruh kegiatan praktek hukum yang ada. Dalam keadaan seperti ini, hukum hanya milik kepentingan-kepentingan tertentu saja. Dalam praksis hukum ini seperti prinsip negara sekuler yang memisahkan agama dengan urusan negara.

Nilai-nilai Islam yang tampak dalam praktek kehidupan sehari-hari masyarakat Indonesia yang telah menyatu dalam sistem kebudayaan belum menjadi kerangka dasar dalam membentuk dan mengimplementasikan hukum positif yang berlaku. Meskipun terdapat redaksi kata-kata yang menyebutkan "Ketuhan Yang Maha Esa" dalam setiap peraturan perundang-undangan, akan tetapi itu hanya berlaku sebagai kalimat awal pembuka yang bersifat formal dan umum, sehingga secara subtansi tidak jelas dan nyata. Nilai-nilai Islam kalah oleh kuatnya tarik-ulur kepentingan politik dan kekuasaan oleh para pejabat pembentuk hukum di negeri ini. Dalam konteks hidup bernegara hukum seperti ini, kekuasaan manusia telah mengalahkan kekuasaan Tuhan. Hal-hal bernilai baik untuk kehidupan manusia yang berwujud perintah dan larangan dari Tuhan untuk manusia 
sebagaimana tertulis dalam kitab suci tidak digunakan dalam menyusun peraturan perundang-undangan. Logika rasional manusia dianggap lebih baik dan mampu memenuhi kepentingan-kepentingan hukum yang ada. Hukum di Indonesia dijalankan hanya untuk mentaati peraturan perundang-undangan belaka, tanpa ada aspek spiritual keagamaan yang juga ikut mempengaruhinya. Oleh karena itu tidak mengherankan jika para pejabat koruptor yang tertangkap Komisi Pemberantasan Korupsi (KPK) adalah mereka yang juga beragama Islam, mengetahui hukum atau ilmu-ilmu Islam, bahkan hafal Al-Quran dan terjemahannya. Mungkin agama bagi mereka bersifat sekuler-personal dan hanya berdimensi vertikal ke atas (Tuhan) yang tidak ada keterkaitanya dengan ketaatan terhadap peraturan perundangundangan yang berlaku. Mereka juga menjalankan ibadah sholat, haji, puasa, zakat dan ritual ibadah lainnya, tetapi masih tetap berperilaku korup, suap, money politik, transaksi kepentingan dan ingin menikmati kekuasaannya untuk kepentingan sendiri. Oleh karena itu, Indonesia perlu mentransformasikan nilai-nilai Islam ke dalam hukum positif nasional. (Prasetyo 2018a, 2-3)

Penelitian ini pada aspek tertentu memiliki kesamaan dengan kajian yang sudah dilakukan oleh para penstudi hukum dan atau agama Islam di Indonesia, yaitu sama-sama mencoba melakukan kajian yang terkait suatu hubungan antara hukum dengan agama. Akan tetapi secara subtansi penelitian ini memiliki perbedaan yang signifikan dengan kajian yang sudah dilakukan, yaitu pada kekhususan kajiannya yang lebih berfokus pada upaya mentransformasikan nilai-nilai Islam ke dalam hukum positif. Berikut beberapa kajian yang sejenis yang dapat dijelaskan perbedaanya dengan penelitian ini.

Penelitian ini berbeda dengan penerapan nilai-nilai islam dalam manajemen zakat sebagaimana yang telah dikemukakan oleh Ira Alia.(Maerani 2012, 959) Penelitian yang dilakukan menjelaskan bagaimana penerapan nilai-nilai islam dalam manajemen zakat daerah di kota semarang dan apa masalah dan solusi dalam penerapan nilai-nilai islam terhadap manajemen zakat hukum di era otonomi daerah di kota semarang. Penelitian ini berbeda dengan penelitian tentang pengembangan hukum Islam di Indonesia yang dilakukan olehAbdul Hadi dan Shofyan Hasan.(Hasan 2015, 89) Dalam penelitiannya lebih pada penjelasan terkait dengan pengembangan hukum Islam yang ditentukan oleh kebijakan politik penguasa. Menurutnya posisi hukum Islam sangat strategis dalam sistem kehidupan nasional karena didukung oleh golongan hukum mayoritas. Selain itu penelitian ini juga berbeda dengan kajian yang dilakukan oleh Jamhari An-Na'im.(Jamhari 2015, 46) tentang suatu sistem baru hukum Islam yang menyeluruh yang diyakini memberikan dasar yang lebih sesuai dengan kehidupan Islam di dunia kontemporer yang merupakan formulasi yang menyeluruh dalam menghadapi struktur politik, tatanan sosial, hukum pidana, hukum internasional dan hak asasi manusia. Terdapat pula kajian yang dilakukan oleh Sahri(Sahri $2013,520)$ tentang hubungan kekuasaan politik dan agama yang saling terkait erat menurut al-Gazzali. Kajiannya mengungkapkan bahwa agama sebagai dasar dan sultan atau negara 
sebagai pelindung. Pembentukan negara dan pemerintahan merupakan tuntutan agama yang tidak bisa diabaikan. Imamah atau pemerintahan itu mengemban tugas pengganti Rusul. Khalifah dalam menjalankan pemerintahannya dianggap sebagai orang suci.

Kajian tentang hukum transendental sebagaimana yang telah dikemukakan oleh Absori(Absori, n.d., 2015) tidak memiliki kesamaan dengan kajian yang dilakukan. Hukum transendental berusaha mengintegrasikan hukum dengan nilai-nilai spriritual agama, etika dan moral. Apabila ditelusuri lebih jauh, asal mula pemikiran hukum transendental adalah bagian dari ilmu pengetahuan sosial profetik yang berbasis pada wahyu (Al-Quran) sebagai dasar metodologinya. Oleh karena itu, hukum transendental pada dasarnya lebih dekat pada kajian filsafat agama sebagai basis epistemologi. Kajian yang hampir sama, tetapi berbeda juga dapat dilihat pada paradigma profetik dalam pembaruan basis epistemologi ilmu hukum yang dikemukakan oleh Kelik Wardiono (Wardiono 2016, 160) yang mendasarkan pada pendekatan filosofis yang diawali dengan upaya melakukan rekontruksi terhadap konsep profetik dari Kuntowijoyo (Kuntowijoyo 1997, 158), dan dilanjutkan dengan upaya memperbarui basis epistemologi ilmu hukum berdasarkan integrasi antara ilmu dan agama. Dari uraian tersebut di atas jelas menunjukkan perbedaan dengan penelitian ini, sehingga orisinalitas dan kebaruan serta pengulangan tema atau ide tidak terjadi.

Kajian tentang memasukkan delik agama ke dalam KUHP yang baru yang dilakukan oleh Ahmad HunaeniZulkarnaen, Kristian, M. Rendi Aridhayandi (Ahmad Hunaeni Zulkarnaen, Kristian 2018, 29) juga tidak memiliki kesamaan dengan penelitian ini. Kajiannya lebih menekankan pada kedudukan Indonesia sebagai negara hukum, sehingga diaturlah kehidupan dan kerukunan hidup antar umat beragama dengan mencantumkan delik-delik agama dalam KUHP yang baru. Hal yang berbeda juga dikaji oleh Mahathir Muhammad Iqbal(Iqbal 2017, 1) tentang fiqh sebagai produk ijtihad. Fiqh merupakan suatu bentuk hukum yang dipengaruhi interaksi antara si pemikir dengan lingkungan sosio-kultural dan sosio-politik yang melingkupinya. Kajian yang terkait juga dilakukan oleh Yassirly Amrona Rosyada (Rosyada 2017, 123) tentang dalalah lafdzi sebagai upaya dalam menemukan hukum selain pada sumber utama Al-Quran dan Hadist, yaitu melalui pemahaman kebahasaan. Dengan pemahaman yang mendalam tentang petunjuk kebahasaan maka hukum Islam dapat dipahami menuju pada pemahaman yang komprehensif.

Islam merupakan agama yang mengandung nilai-nilai kehidupan yang baik bagi umat manusia. Hal ini seperti prinsip maqasidsyari'ahyang dikembangkan olehal-Syatibi (Al-Syatibi 1997, 324), bahwa tujuan utama hukum Islam adalah untuk kemaslahatan manusia di dunia dan di akherat. Dalam mencapai kemaslahatan tersebut, pada tingkat yang paling utama yaitu menjaga agama, jiwa, akal, kehormatan dan keturunan serta harta. Semua umat manusia tentu sepakat dengan perlindungan terhadap hak-hak yang bersifat asasi tersebut. Peran maqashid syari'ah dalam pengembangan hukum cukup penting, 
karena dapat dijadikan alat bantu untuk memahami Al-Quran dan Sunnah, dalil-dalil yang bertentangan dan menetapkan hukum terhadap kasus-kasus yang tidak diatur dalam AlQuran dan Sunnah. Dalam memahami perkembangan zaman yang terus berubah, maka maqashid syari'ah menjadi metode yang dinamis untuk mengikuti perkembangan. Bahkan dengan metode tersebut mampu untuk menjelaskan hukum-hukum Islam secara logis dan ilmiah, sehingga dapat diterima umat secara universal.

Islam bukan hanya sekedar agama, tetapi juga merupakan pandangan tentang ilmu pengetahuan, karena Islam menghargai dan menjunjung tinggi ilmu pengetahuan. Ibadah tanpa dilandasi ilmu pengetahuan tidak bernilai apapun, sedangkan berilmu pengetahuan tanpa dasar ibadah akan mengkufurkan manusia. Oleh sebab itu Islam mengarahkan semua kegiatan secara ilmiyah. Seperti pandangan tentang keilmiahan Islam dalam AlQuran yang dapat dapahami dengan metodologi filsafat yang berbasis indera, akal dan hati nurani (Sardar 2000, 23). Islam memiliki metode yang khas untuk memahami pengetahuan seperti disebutkan oleh al-Jabiri(Al-Jabiri 2003, 3), yaitu bayani, burhani dan irfani. Metode bayani yang menghasilkan pengetahuan dengan membaca teks secara langsung atau tidak langsung melalui analogi (qiyas). Metode burhani yang menghasilkan pengetahuan melalui logika akal dengan pendekatan deduktif. Metode irfani yang menghasilkan pengetahuan melalui intuisi hati nurani (Al-Jabiri 1991). Dalam metode bayani peran indera sangat penting, karena memerlukan indera (telinga dan mata) untuk mendengar dan melihat. Sedangkan dalam burhani peran akal sangat penting, karena menghasilkan pengetahuan melalui logika rasional. Dalam metode irfani peran hati nurani sangat penting, karena menghasilkan pengetahuan melalui intuisi. Allah SWT menganugrahkan, mewajibkan dan meminta pertanggungjawaban manusia dalam menggunakan indera, akal dan hati nurani untuk memperoleh pengetahuan (Q.S, al-Mukminun: 78).

Dalam proses memperoleh dan mengamalkan ilmu pengetahuan Islam telah memiliki prinsip yang wajib dilakukan, karena itu bagian dari nilai-nilai yang tidak dapat dikesampingkan begitu saja. Hal ini terwujudkan dengan adanya adab Islam terhadap ilmu pengetahuan. Adab disini dipahami sebagai suatu pengenalan dan pengakuan terhadap realitas bahwa ilmu pengetahuan dan segala sesuatu yang ada terdiri dari hierarki yang sesuai dengan kategori dan tingkatan, kapasitas, potensi, intelektual dan spiritual. Sehingga manusia harus memahami dirinya sesuai dengan adabnya sebagai mahluk ciptaan Allah SWT dengan segala aspek kemampuan dan kelemahan yang dimilikinya. (Al-Attas 2001, 47) memberi makna adab lebih dalam dan komprehensif yang berkaitan dengan objek-objek tertentu, seperti pribadi manusia, ilmu, bahasa, sosial, alam dan Tuhan. Beradab berarti menerapkan adab kepada masing-masing objek tersebut dengan benar dan sesuai dengan aturan hukum. sehingga dalam hal ini adab telah menjadi asas-asas hukum yang wajib ditaati, bukan hanya karena sifatnya yang normatif, tetapi karena keterkaitannya dengan sifat dasar yang utama sebagai pedoman manusia untuk kebaikan hidup manusia.

al-ạ̣kām Vol. 5, Nomor 1, 2020 
Dalam penelitian ini menggunakan metode penelitian sosciological jurisprudence yang mengkaji hukum sebagai perilaku yang terkait dengan sistem norma hukum positif(Freeman 2001, 659), seperti yang dilakukan oleh para juris di Amerika; Oliver W. Holmes, Cardozo dan Roscoe Pound (Tamanaha 2008, 54). Objek penelitian menganai perilaku masyarakat atas diterapkannya sistem norma hukum positif dan sebagai bentuk perilaku masyarakat dalam mempengaruhi pembentukan sistem norma hukum positif, serta untuk mengetahui efektifitas bekerjanya hukum dalam masyarakat. Pendekatan yang digunakan dalam penelitian ini adalah filsafat hukum yang dapat memberi informasi, ferivikasi, koreksi, pelengkap dan penjelasan secara lebih rinci (Zubair 1990, 94). Data yang digunakan dalam penelitian ini adalah data primer, yaitu data yang diperoleh dari kajian yuridis sosiologis yang dipraktekkan di masyarakat. Data dikumpulkan dengan metode observasi, yaitu proses kegiatan untuk mengumpulkan data dengan cara mengamati fenomena hukum di masyarakat. Analisis data dilakukan dengan tiga cara. Pertama, analisis deskriptif untuk memberikan gambaran secara menyeluruh dan nyata tentang hukum sebagai bentuk perilaku masyarakat. Kedua analisis evaluatif untuk memberikan justifikasi penilaian terhadap fakta hukum. Ketiga analisis preskriptif untuk memberikan argumentasi terhadap fakta hukum mengenai benar atau salah dan bagaimana yang seharusnya menurut hukum.

\section{Hukum Positif Kering Dari Nilai-Nilai Islam}

Indonesia harus mengakui bahwa sejak kemerdekaan 17 Agustus 1945 hingga sampai sekarang belum mampu lepas dari hukum yang dibuat oleh penjajah Belanda. Hal itu dapat dilihat dan dirasakan dengan jelas dari sistem hukum "civil law system" yang digunakan Indonesia. Inti dari prinsip sistem hukum tersebut adalah asas legalitas positif hukum, artinya hukum merupakan suatu peraturan perundang-undangan tertulis yang dibentuk oleh lembaga negara yang berwenang untuk itu, dan selain itu tidak dianggap sebagai hukum. Begitu kuatnya dominasi penguasa negara dalam menentukan hukum menjadi cirikhas karakter dari sistem hukum ini. Dalam sistem hukum tersebut sebenarnya telah menunjukkan sistem hukum Barat (asing) yang dipakai sebagai arah kiblat untuk hukum di Indonesia. Hukum tersebut berarti a-historis, karena tidak berasal dari realitas sejarah masyarakat asli Indonesia. Indonesia sebenarnya telah dipaksa oleh penjajah Belanda untuk menggunakan hukum-hukum yang tidak sesuai dengan prinsip-prinsip dan nilai-nilai kehidupan sosial budaya masyarakat. Berbagai hukum positif nasional yang masih merujuk pada dasar-dasar hukum bekas penjajah Belanda, seperti; hukum tata negara, hukum administrasi negara, hukum Pidana dan hukum perdata. Entah apa yang membuat negara Indonesia begitu susah dan sangat tergantung dari hukum bekas penjajah Belanda tersebut. 
Dampak dari pemakaian hukum warisan penjajah Belanda tersebut adalah hilangnya kerangka dasar pembentuk otentitas hukum asli Indonesia yang bersumber dari nilainilai kehidupan sosial budaya masyarakat, termasuk nilai-nilai Islam. Sebagaimana sistem hukum yang dijalankan di negara asal Belanda, tentunya hukum tidak mengandung nilainlai Islam, karena basis masyarakat tidak beragama Islam. Seluruh prosedur rancangan, pembentukan dan implementasi hukum telah ditentukan sedemikian rupa dengan standart logika tertutup sebagaimana maksud dari peraturan perundang-undangan (Prasetyo 2018 b, 3). Segala hukum harus mendapat pengakuap secara logis dan rasional dalam hukum, sekalipun itu nilai-nilai agama. Sehingga sulit kiranya untuk menanamkan nilai-nilai Islam ke dalam hukum positif nasional jika sistem hukum yang digunakan seperti itu. Dalam hukum warisan penjajah Belanda tidak mengenal adanya prinsip untuk mengkoneksikan keterkaitan hukum dengan niali-nilai agama, karena hukum dianggap memiliki wilayah sendiri yang netral dari unsur-unsur apapun dan agama dipandang sebagai bagian dari unsur yang dapat mengurangi netralitas hukum. Cara-cara belajar dan mengimplentasikan hukum yang dilakukan oleh penjajah Belanda ditiru dan diikuti Indonesia, sehingga hasilnya hukum terasa asing bagi masyarakat Indonesia sendiri.

Hukum di Indonesia yang identik dengan peraturan perundang-undangan pada dasarnya merupakan hasil dari kerja para politikus di lembaga perwakilan rakyat (DPR). Oleh karena itu tidak mengherankan jika peraturan perundang-undangan syarat dengan muatan kepentingan politik dan kekuasaan. Para pembentuk hukum adalah mereka para politikus yang mewakili partai politiknya di lembaga legislatif, sehingga jelas akan mengutamakan kepentingan partai politiknya daripada kepentingan yang lain. Tendensi kepentingan politik lebih kuat pengaruhnya daripada penanaman nilai-nilai kehidupan dan agama dalam hukum. Sebagai produk politik, maka hukum lebih terasa sebagai kebijakan politik kekuasaan yang dibentuk untuk tujuan tertentu dan tidak berpengaruh positif secara langsung kepada masyarakat. Bahkan peraturan perundang-undangan yang dibentuk disadari atau tidak telah melenceng jauh dari nilai-nilai kehidupan masyarakat yang ada, terutama nilai-nilai budaya dan agama (Islam). Seperti contoh adalah nilai-nilai kesederhanaan dan kebijaksanaan pemimpin yang telah menjadi ajaran para leluhur bangsa dan juga merupakan ajaran dalam agama Islam tidak tampak dalam hukum positif negara. Pemegang kekuasaan negara lebih suka dengan gaya hidup mewah bergelimang banyak harta kekayaan dan ingin selalu diistimewakan serta diperlakukan lebih dari masyarakat yang lain. Nilai-nilai keteladanan yang baik yang diajarkan oleh Islam seperti kepemimpinan Rosullullah dan para khalifah bertolakbelakang dengan realitas kebobrokan moral para elit politik pemimpin bangsa ini yang suka berbuat korup.

Hukum yang dibentuk oleh lembaga legislatif yang di dalamnya terdiri dari para elit politik perlu dikaji lebih dalam, karena elit-elit politik tersebut terdiri dari beraneka ragam latar belakang pendidikan dan pekerjaannya, apakah mereka memiliki kualifikasi dan

al-ạ̣kān Vol. 5, Nomor 1, 2020 
kompetensi untuk membentuk peraturan perundang-undangan. Pekerjaan membentuk peraturan perundang-undangan memerlukan keahlian khusus yang hanya dimiliki oleh orang-orang yang bekerja dan berpendidikan di bidang ilmu hukum, karena tidak mungkin seorang pengusaha properti atau rumah makan yang menjadi anggota legislatif akan membuat peraturan perundang-undangan. Meskipun dalam lembaga legislatif terdapat staf ahli dibidang hukum, tetapi mereka hanya bertugas untuk mengarahkan dan membimbing prosedur pembuatan teknis hukum, bukan menentukan subtansi isi dari hukum itu dan tidak memiliki kewenangan untuk menentukan hukum. Jika demikian, maka kita akan ingat ajaran Islam yang telah menjelaskan bahwa jika suatu pekerjaan tidak dikerjakan oleh ahlinya, maka tinggal menunggu kehancurannya. Istilah tersebut seperti menunjukkan potret buruk hukum di Indonesia. Ilmu pengetahuan merupakan hal yang sangat penting dalam suatu pekerjaan, tidak hanya Islam yang mengutamakan ilmu pengetahuan dalam suatu pekerjaan, tetapi dunia profesional juga menerapkan standart yang sama. Akibat dari mengabaikan ilmu pengetahuan di bidang hukum, negara Indonesia mengalami stagnansi perkembangan hukum. Indonesia masih menggunakan hukum warisan penjajah Belanda. Hukum tidak pernah diperbaruhi sesuai dengan perkembangan sosial masyarakat yang ada. Islam sebagai agama yang telah dianut sebagaian besar mayoritas masyarakat Indonesia, nilai-nilai ajarannya tidak digunakan sebagai kerangka dasar dalam membentuk hukum positif nasional.

Hukum di Indonesia hanya terasa sebagai alat untuk melaksanakan peraturan perundang-undangan. Terlaksanakannya peraturan perundang-undangan sesuai dengan bunyi teks yang ada sudah cukup untuk menilai apakah hukum telah mencapai tujuan, terlepas dari apakah hal itu baik atau buruk (Prasetyo 2018c, 95). Civil law system yang ditopang oleh paradigma positivisme hukum yang berlaku di Indonesia menjadikan hukum terasa kaku dan anti perubahan, apa yang telah tertulis dalam peraturan perundangundangan harus menjadi pedoman utama hukum dan diluar itu tidak dianggap sebagai hukum yang harus ditaati. Asas legalitas dalam hukum positif di Indonesia hanya menempatkan aparat penegak hukum sebagai corong undang-undang atau sebagai robotrobot yang telah diprogram sedemikian rupa. Mereka hanya bertugas menjalankan undangundang, tanpa harus berpikir aspek-aspek lain yang mempengaruhinya. Mereka lebih mengandalkan penafsiran gramatikal dan cenderung tekstual secara leksikal sebagaimana bunyi dalam peraturan perundang-undangan. Penafsiran tersebut sebenarnya hanyalah salah satu metode penemuan hukum (rechtsvinding) saja. Meskipun di luar dikenal metodemetode lain seperti konstruksi, argumentasi dan hermeneutik, namun mereka umumnya sering bermain di wilayah aman dengan metode penafsiran konvensional. Jarang mereka yang menyeberang ke metode lain. Hakim dalam hukum pidana bahkan mengharamkan penggunaan "argumentum per analogiam" karena dianggap bertentangan dengan asas legalitas. Larangan ini tidak sekedar doktrin, melainkan sudah diformulasikan secara tegas 
dalam asas legalitas "nullum delictum nulla poena sine praevia lege poenali" yang diatur dalam pasal 1 ayat (1) KUHP.

Tujuan kepastian dalam hukum lebih tinggi nilainya dari kebenaran subtansi atau moral dan bahka nilai-nilai agama. Hal tersebut dapat dilihat dari kasus penegakkan hukum yang menimbulkan kontroversi di masyarakat, seperti kasus Nenek Asiani yang harus dipenjara karena dituduh mencuri ranting kayu jati, Tukirin yang harus dipenjara karena dituduh mencuri satu tongkol jagung dan Kasman yang dipenjara karena dianggap telah mencuri dua butir semangka. Praktek-praktek hukum seperti ini sebenarnya jauh dari nilainilai kehidupan sosial budaya dan agama masyarakat Indonesia. Budaya ramah, empati dan kasih sayang yang diajarkan dalam nilai-nilai Islam dalam kasus ini tidak ada, karena kalah dengan asas legalitas dalam hukum positif nasional. Sikap-sikap bijaksana dengan memberikan kemanfaatan yang banyak bagi manusia yang lain sebagaimana diajarkan nilai-nilai Islam dalam pergaulan hidup sosial masyarakat dalam penegakkan hukum positif bukan merupakan suatu aspek penting dari dimensi hukum yang harus diikuti. Meskipun itu baik dan bersumber dari nilai-nilai agama, tetapi jika tidak di legalisasi oleh hukum positif, maka hal itu bukan merupakan hukum, sehingga dapat dikesampingkan begitu saja. Caracara seperti inilah yang dapat menghilangkan nilai-nilai Islam dalam hukum positif nasional Indonesia. Hukum di Indonesia seperti hukum bagi orang-orang yang tidak beragama, atau minimal seperti orang-orang yang hanya berlebel "Islam KTP".

\section{Konsep Transformasi Nilai-Nilai Islam ke Dalam Hukum Positif}

Nilai-nilai Islam dapat dipahami sebagai sesuatu inti dari kehidupan Islam yang penting atau berguna bagi manusia. Sehingga nilai-nilai Islam merupakan kualitas dari Islam yang menjadikan Islam disukai, diinginkan, dihargai, berguna dan suatu yang terpenting atau berharga bagi manusia. Dengan demikian, maka sebenarnya nilai-nilai Islam sangat luas yang mencakup segala aspek kehidupan manusia yang bernilai positif. Hal ini seperti segala sesuatu yang mensyaratkan adanya ketaukhidan, aqidah dan ahklak pada dasarnya adalah nilai-nilai Islam yang masih bersifat umum dan perlu dijabarkan lebih lanjut(Djamal 2017, 169). Dalam memahami nilai-nilai Islam perlu penafsiran yang bersifat dinamis dan kompatibel (Mutamakkin 2011, 302), karena menyangkut dengan segala penciptaan Tuhan sebagai pemegang kekuasaan penuh atas apa yang telah terjadi, sedang terjadi dan akan terjadi. Islam sebagai agama yang menjunjung tinggi ilmu pengetahuan telah memerintahkan umatnya untuk selalu memperbaiki diri dengan memahami dan mengambil pelajaran dari perkembangan kehidupan manusia dengan mengambil yang baik dan membuang yang tidak baik (Hidayatullah 2019, 127). Artinya, bahwa nilai-nilai Islam merupakan suatu dasar-dasar yang bersifat umum yang masih perlu dijabarkan secara luas sesuai dengan perkembangan zaman dalam rangka mengambil unsur-unsur positif yang berguna dalam

al-ạ̣kām Vol. 5, Nomor 1, 2020 
kehidupan manusia. Seperti dijelaskan dalam Al-Quran dan Hadist, bahwa segala penciptaan Tuhan tidak ada yang sia-sia, karena disitu akan ditemukan makna-makna yang beguna bagi manusia. Segala bentuk pemikiran, sikap dan tingkah laku manusia yang dilandasi niat karena Allah pada prinsipnya merupakan nilai-nilai Islam yang penting untuk menjadi pegangan utama dalam kehidupan manusia (Patmawati 2016, 185-86). Oleh karena itu, dalam memahami nilai-nilai Islam perlu suatu cara pandang yang luas dan bijaksana agar benar-benar dapat menemukan hikmah dari Tuhan yang telah disebar ke dunia melalui rahmat dan karunianya yang tak terhingga.

Nilai-nilai agama berfungsi untuk menjelaskan kehidupan dunia sehingga dapat memberikan peringatan dan menghindarkan manusia dari kerusakan dan kehancuran. Nilai-nilai agama akan tetap menjadi tujuan dan way of life bagi seluruh manusia dalam berbagai jaman yang berbeda (Mulyadi 2019, 63). Nilai-nilai Islam sebenarnya diarahkan untuk meneguhkan kedudukan manusia sebagai mahluk ciptaan Tuhan yang paling sempurna dibandingkan dengan mahluk yang lain. Tuhan telah memberikan indera, akal dan hati nurani kepada manusia untuk menjadikan ia sebagai insan khamil yang sempurna dan utuh lahir-batin(Prasetyo 2018b, 208). Dengan anugerah tersebut manusia diharapkan mampu menjaga dirinya untuk selalu menjalankan perintah dan menjauhi larangan yang telah ditetapkan Tuhan. Al-Quran sebagai sumber hukum utama dalam Islam mengandung berbagai pengajaran nilai-nilai yang penting bagi manusia. Bagaimana manusia harus bersikap dalam hidup agar mendapatkan keselamatan dunia dan akherat menjadi prinsip nilai utama yang paling banyak dijelaskan dalam Al-Quran(Satjono 2005, 135). Contoh kisahkisah kehidupan para Nabi dan Rosul serta orang-orang yang durhaka kepada Allah pada dasarnya juga mengandung nilai-nilai yang nyata sebagai pengajaran bagi umat manusia. Petunjuk jalan kebaikan yang telah ditetapkan Tuhan untuk mengatur umatnya adalah nilainilai yang harus dijadikan pedoman hidup manusia agar mendapat keselamatan. Adanya gambaran kehidupan setelah mati sebagai pembalasan dari amal perbuatan manusia di dunia memiliki makna nilai yang menyenangkan dan menakutkan bagi manusia. Oleh karena itu nilai-nilai Islam sebagai keyakinan dan konsep yang dijunjung tinggi oleh manusia mengenai beberapa masalah pokok yang berhubungan dengan Islam untuk dijadikan pedoman dalam bertingkah laku (Halimang 2016, 77-78), baik nilai-nilai yang bersumber dari kitab maupun hasil interaksi manusia yang tidak bertentangan dengan syariat Islam.

Islam pada hakikatnya telah mengatur segala bidang kehidupan manusia, dari hal-hal yang kecil bersifat pribadi sampai pada hal-hal besar yang bersifat umum. Artinya banyak sekali penjelasan tema-tema kehidupan dalam Islam yang dapat dilihat kesesuaiannya dengan hukum positif nasional. Meskipun perlu penjelasan lebih lanjut, akan tetapi inti dari kandungan nilai-nilai Islam dapat dipahami maksudnya dan disingkronisasikan dengan halhal yang diatur dalam peraturan peundang-undangan. Nilai-nilai Islam yang memiliki prinsip dasar fundamental membuat pemahaman menjadi fleksibel dan dinamis, sehingga hal ini 
dapat memudahkan melakukan transformasi nilai-nilai ke dalam hukum positif nasional. Hal ini sesuai dengan makna pemahaman dalam Al-Quran yang luas dan dalamnya tidak terhingga, dan manusia hanya mampu memahami sebagian kecil dari hal itu, padahal masih banyak rahasia pengetahuan lain yang tidak pernah akan sanggup dicapai oleh manusia, karena itu merupakan ilmu Allah yang menguasasi segala-galanya. Nilai-nilai Islam pada dasarnya dapat dipahami secara universal yang dapat diterima oleh semua pihak, termasuk orang-orang yang bukan beragama Islam. Nilai-nilai kebaikan yang diajarkan oleh Islam tidak hanya berguna bagi kebaikan umat Islam saja, tetapi bagi umat yang lain juga dapat merasakan kebaikan tersebut. Sehingga tidak ada alasan untuk bangsa ini untuk memisahkan nilai-nilai Islam dengan hukum positif nasional. Tafsir penjelasan nilai-nilai Islam ke dalam hukum positif nasioanl harus disusun sesuai dengan kultur budaya masyarakat Indonesia, agar lebih mudah untuk diterima dan dipahami bersama. Seperti menanamkan nilai-nilai kebaikan hidup yang dapat diterima baik pula oleh yang lain, karena nilai kebaikan pada prinsipnya sama sepanjang tidak bertentangan dengan syariat Islam. Dalam hal demikian berarti juga merupakan prinsip dari sunattullah ajaran Islam dalam mengikuti perkembangan yang ada. Bagi orang Indonesia yang mayoritas telah beragama Islam, maka tidak lah sulit untuk memahami nilai-nilai Islam, apalagi didukung dengan akulturasi budaya masyarakat sehari-hari yang telah menyatu dengan ajaran Islam menjadikan nilai-nilai Islam bagian dari sistem kehidupan sehari-hari mereka (Kurniawan 2019, 68-69).

Transformasi nilai-nilai Islam ke dalam hukum positif nasional melalui metode sinkronisasi tematik merupakan cara yang paling mudah dan sederhana, karena hanya cukup dengan melakukan penyesuaian untuk mencapai pemahaman hukum yang baik yang juga memiliki dimensi spiritualitas keagamaan. Seperti contoh tema ketatanegaraan, bagaimana pejabat mengatur negara ini, agar sesuai dengan nilai-nilai islam. Maka pejabat tersebut harus memiliki aqidah dan ahklak yang baik, dengan prinsip bahwa jabatan adalah amanah yang harus dipertanggungjawabkan secara hukum positif dan juga kepada Tuhan, pejabat lebih mengutamakan kepentingan rakyat, bersikap adil, tidak korup, tidak ingin diperlakukan lebih dan tidak hanya menumpuk kekayaan pribadi. Jika dirasakan, maka hukum positif yang mengatur tentang itu di Indonesia jauh dari nilai-nilai tersebut, karena yang tampak adalah pejabat tidak takut dosa, seolah-olah Tuhan tidak mengawasinya, ahklak yang buruk, tidak membela kepentingan rakyat, sikap yang korup, selalu ingin diperlakukan lebih dari rakyatnya, meminta gaji tinggi, hanya menumpuk harta kekayaan pribadi dan suka mempermainkan hukum untuk mengatur siasat tertentu demi mencapai tujuannya. Selain itu di bidang-bidang hukum yang lain, bagaimana hukum harus diberlakukan secara adil sesuai dengan nilai-nilai Islam, maka prinsip utamanya adalah dengan melindungi korban atau pihak yang lemah dan memberikan sanksi hukum kepada siapa saja yang bersalah sesuai dengan prinsip kebijaksanaan. Artinya hukuman dilaksanakan dengan tujuan utama untuk memperbaiki kesalahan menjadi baik kembali, bukan hanya sebagai sarana balas dendam 
kejahatan yang telah dilakukan seseorang. Hal ini seperti dengan tidak hanya menghukum pelaku tindak kejahatan, tetapi juga membimbingnya untuk bertobat dan kembali ke jalan yang baik, serta tidak lupa memberi ganti rugi yang bermanfaat bagi korban.

Mentransformasikan nilai-nilai Islam ke dalam hukum positif nasional berarti mengintegrasikan Islam dengan peraturan perundang-undangan yang berlaku. Hukum positif nasional yang kering dari dimensi spiritual keagamaan akan menjadi lebih religius dengan nuansa Islam yang tetap memiliki karakter ke-Indonesiaan. Dalam kehidupan masyarakat Indonesia yang mayoritas beragama Islam, akulturasi Islam dengan budaya adat lokal menjadi tata aturan yang dipakai dalam kehidupan sehari-hari, sehingga Islam dan budaya adat lokal telah menjadi satu kesatuan nilai-nilai kehidupan yang ada dalam masyarakat Indonesia (Idi Warsah, Dewi Cahyani 2019, 16-17). Oleh karena itu nilai-nilai kehidupan tersebut seharusnya menjadi dasar utama dalam membentuk hukum positif nasional. Transformasi nilai-nilai Islam ke dalam hukum positif nasional dapat menyatukan hukum yang telah lama terdikotomik dan sekuler akibat dari sistem hukum peningggalan penjajah Belanda. Meskipun tidak secara langsung tertulis seperti dalam pemberlakuan hukum syariah, transformasi nilai-nilai Islam seperti membangun peradaban Islam di suatu negara yang bukan negara Islam. Hal ini jauh lebih penting daripada pemaksaan pembentukan negara Islam di Indonesia, karena secara historis Indonesia memang bukan negara yang berideologi Islam, tetapi ideologi Pancasila. Islam merupakan agama yang bijak dalam menghadapi kehidupan, sehingga mampu dipahami dalam keadaan apapun. Islam tidak perlu diteriakkan dengan keras, tetapi cukup dengan menunjukkan pada sikap dan perilaku yang mencerminkan nilai-nilai kebaikan hidup manusia. Hukum yang terintegrasi dengan nilai-nilai Islam akan terasa hingga pada aplikasi nyata dalam praktek kehiduan, sehingga bukan hanya sekedar hukum yang bersifat normatif tertulis dalam peraturan perundang-undangan yang sering dilanggar, tetapi benar-benar dapat diwujudkan dalam tindakan yang nyata.

Indonesia memerlukan transformasi nilai-nilai agama ke dalam hukum positif nasional untuk menjembatani terputusnya hubungan integrasi diantara keduanya. Peradaban Islam yang diharapkan dalam kehidupan bernegara ini dapat tercapai dengan cara-cara yang mampu menjamin terlaksananya sistem hukum yang lebih baik. Integrasi hukum dengan agama melalui transformasi nilai-nilai Islam mampu meminilimalisir tendensi kepentingan yang bersifat pribadi atau kelompok. Meskipun hukum positif nasional tidak mengawasi perbuatan seseorang, tetapi dengan nilai-nilai Islam seseorang akan selalu merasa terawasi oleh Tuhan. Tujuan utama hukum bukan hanya sekedar mengatur dan memberi sanksi, tetapi juga memperbaiki sikap karakter moralitas dan ahklak manusia agar menyadari dirinya sebagai mahluk Tuhan yang baik. Kepentingan hukum positif nasional yang bersifat materialisme perlu diseimbangkan dengan nilai-nilai Islam yang menekankan pada dimensi mental spiritual dalam aspek ukhrowi. Menempatkan nilai-nilai Islam dalam hukum positif 
nasional merupakan bentuk dari tingkat keimanan tetinggi dari suatu bangsa yang memiliki peradaban mulia. Negara yang "baldatun thayyibatun wa robbun ghafur" dapat tercapai dengan cara-cara yang diatur hukum menggunakan nilai-nilai Islami. Membangun peradaban Islam dengan mentransformasikan nilai-nilai Islam bukan berarti memberlakukan syariat Islam secara langsung, tetapi lebih pada upaya untuk menggunakan nilai-nilai Islam yang diyakini baik, penting dan bermanfaat untuk mengatur kehidupan masyarakat.

\section{Kesimpulan}

Hukum positif nasional Indonesia mengalami permasalahan yang serius, yaitu kekeringan dari dimensi spiritual agama. Hukum hanya dipahami sebagai bentuk peraturan perundang-undangan tertulis yang dibentuk oleh lembaga berwenang negara yang bertujuan untuk mencapai kepastian hukum, terlepas dari apakah hal itu baik atau buruk. Selain dari yang diatur di dalam peraturan perundang-undangan bukan disebut sebagai hukum, sehingga tidak perlu ditaati, termasuk ajaran agama. Hukum positif dipahami terpisah dari unsur agama, karena memiliki wilayah pengaturan yang berbeda, sehingga hukum dan agama tidak dapat dicampur. Dalam hukum positif tidak mengenal apa itu dosa, yang ada hanya sanksi-sanksi yang diancam dengan hukuman denda atau penjara. Tindak pelanggaran hukum yang dilakukan seseorang di dunia dipahami tidak akan berdampak pada kehidupannya di akherat setelah mati. Permasalahan hukum ini timbul dari akibat Indonesia masih memakai sistem hukum peninggalan penjajah Belanda yang hanya menekankan pada aspek pembalasan hukum di dunia. Civil law system warisan penjajah Belanda telah mempengaruhi seluruh sistem hukum nasional Indonesia, mulai dari pembentukan hingga pelaksanaan hukum yang jauh dari nilai-nilai Islam. Hukum positif lebih mengutamaakan kepentingan pejabat penguasa negara daripada rakyat. Sebagai akibatnya banyak pejabat penguasa negara yang mempermainkan hukum dan melanggar hukum untuk mencapai tujuan pribadi atau kelompoknya saja.

Dalam hukum positif nasional Indonesia perlu mentransformasikan nilai-nilai Islam, agar hukum tidak tersesat jauh dari jalan benar yang telah ditentukan Tuhan. Melaksanakan hukum positif harus dipahami tidak hanya sekedar mentaati peraturan perundang-undangan negara, tetapi juga merupakan bentuk ibadah kepada Tuhan. Mentransformasikan nilainilai Islam ke dalam sistem hukum positif nasional bukan berarti menerapkan syariat Islam secara langsung sesuai dengaan Al-Quran dan Hadist, tetapi lebih pada menggunakan makna atau hakikat dari ajaran Islam yang diyakini penting dan baik untuk kehidupan manusia, seperti nilai-nilai aqidah dan ahklak yang baik. Islam mengajarkan manusia untuk selalu menjalankan perintah Tuhan dan menjauhi laranganya. Transformasi dapat dilakukan dengan singkronisasi tematik nilai-nilai Islam dengan peraturan perundang-undangan yang ada, karena nilai-nilai Islam yang bersifat umum dan fundamental dapat digunakan

al-ạ̣kām Vol. 5, Nomor 1, 2020 
sebagai pedoman dasar untuk membentuk peraturan perundang-undangan. Islam telah mengajarkan banyak hal untuk mengatur kebaikan hidup manusia yang dapat diambil nilainilainya, sehingga hal itu dapat dipakai pula dalam peraturan perundang-undangan. Konsep ini juga merupakan bentuk dari integrasi hukum dan agama, sehingga hukum memiliki semangat dan jiwa spiritualitas. Dengan demikian, transformasi nilai-nilai Islam ke dalam hukum positif nasional sebagai bentuk upaya membangun peradaban Islam di Indonesia tanpa harus dengan mendirikan negara Islam.

\section{Daftar Pustaka}

Absori. n.d. "Epistimologi Ilmu Hukum Transendental Dan Implementasinya Dalam Pengembangan Program Doktor Ilmu Hukum", Seminar Nasional Pengembangan Epistimologi Ilmu Hukum."

Ahmad Hunaeni Zulkarnaen, Kristian, M. Rendi Aridhayandi. 2018. "Kebijakan Formulasi Delik Agama Dalam Kitab Undang-Undang Hukum Pidana Yang Baru." Al-Ahkam Jurnal IlmuSyari'ah Dan Hukum Vol.3, No.

Al-Attas, Syed Muhammad Naquib. 2001. Risalah Untuk Kaum Muslimin. Kuala Lumpur: ISTAC.

Al-Jabiri, Muhammad Abed. 1991. Bunyah Al-Aql Al-Arabi. Beirut: al-Markaz al-Tsaqafi alArabi.

-- - 2003. Kritik Kontemporer Atas Filsafat Arab-Islam, Terjemah Oleh Moch Nur Ichwan. Yogyakarta: Islamika.

Al-Syatibi, Abu Ishaq. 1997. Al-Muwafaqat. Bairut: Darul Ma'rifah.

Djamal, Samhi Muawan. 2017. "Penerapan Nilai-Nilai Ajaran Islam Dalam Kehidupan Masyarakat Di Desa Garuntungan Kecamatan Kindang Kabupaten Bulukumba." Jurnal Adabiyah Vol.17, No.

Freeman, M.D.A. 2001. Introduction to Jurisprudence. London: Sweet \& Maxwell LTD.

Halimang, St. 2016. "Salat Dan Kesehatan Perspektif Maqasid Al-Syariah." Khatulistiwa: Journal of Islamic Studies Vol.6, No.

Hasan, Abdul Hadi dan Shofyan. 2015. "Pengaruh Hukum Islam Dalam Pengembangan Hukum Di Indonesia." Jurnal Nurani Vol.15, No.

Hidayatullah, Syarif. 2019. "Agama Dan Sains: Sebuah Kajian Tentang Relasi Dan Metodologi." Jurnal Filsafat UGM Vol.29, No.

Idi Warsah, Dewi Cahyani, Rahmi Pratiwi. 2019. "Islamic Integration And Tolerance In Community Behaviour; Multiculturalism Model In The Rejang Lebong District." Khatulistiwa: Journal of Islamic Studies Vol.9, No.

Iqbal, Mahathir Muhammad. 2017. "Merumuskan Konsep Fiqh Islam Perspektif Indonesia." Al-Ahkam Jurnal Ilmu Syari'ah Dan Hukum Vol.2, No. 
Jamhari. 2015. "Reformasi Syari'ah Dan Wacana Hak Asasi Manusia." Jurnal Nurani Vol. 15, N.

Kuntowijoyo. 1997. Identitas Politik Umat Islam. Bandung: Mizan.

Kurniawan, Bayu Suratman; Syamsul. 2019. "Tudang Sipulung in Muslim Community of Peniti Luar (Identity, Islamic Value and Character Building)." Khatulistiwa: Journal of Islamic Studies Vol.9, No.

Maerani, Ira Alia. 2012. “Aplikasi Nilai-Nilai Islam Dalam Peraturan Daerah (Perda) Tentang Pengelolaan Zakat Dan Problematikanya Pada Era Otonomi Daerah Di Kota Semarang." Jurnal Hukum XXVIII, No.

Mulyadi. 2019. "Pemerintahan, Demokrasi, Dan Interpretasi Agama Dalam Perspektif Abdul Karim Soroush." Jurnal Filsafat UGM Vol.29, No.

Mutamakkin, Billa. 2011. "Pemaknaan Teologis M. Fethullah Gulen Tentang Relasi Agama Dan Sains, Teosofi,." Jurnal Tasawuf Dan Pemikiran Islam Vol.1, No.

Patmawati. 2016. "Peranan Nilai Philosofi Bugis Terhadap Proses Pengislaman Kerajaan Bugis Makassar Di Sulawesi Selatan." Khatulistiwa: Journal of Islamic Studies Vol.6, No.

Prasetyo, Yogi \& Absori. 2018a. "Convergence Epistemologies Of Legal Studies Perspectives Of Islamic Philosophy." Millati: Journal of Islamic Studies and Humanities Vol.3, No.

- - . 2018b. "Integral Education Of The Religious Base ToStraighten The Minds Of The State Of Indonesia." Journal of Advances in Social Science and Humanities Vol.4 (6).

- - . 2018c. "Irfaniy as Epistemology Method Sufism Based on Conscience." Tsaqafah: Jurnal Peradaban Islam Vol.14, No.

Rosyada, Yassirly Amrona. 2017. "Dalalah Lafdzi: Upaya Menemukan Hukum." Al-Ahkam Jurnal IImu Syari'ah Dan Hukum Vol.2, No.

Sahri. 2013. "Konsep Negara Dan Pemerintahan Dalam Perspektif Fikih Siyasah Al-Gazzali." Jurnal Asy-Syir'ah Ilmu Syari'ah Dan Hukum Vol. 47, N.

Sardar, Ziauddin. 2000. Merombak Pola Pikir Intelektual Muslim, Terjemah Oleh Agung Prihantoro \& Fuad A.F. Yogyakarta: Pustaka Pelajar.

Satjono. 2005. "Nilai-Nilai Dasar Pendidikan Islam." Jurnal Pendidikan Agama Islam Vol.II, No.

Tamanaha, Brian Z. 2008. Understanding Legal Realism, Legal Studies Research Paper Series. ST John's University School of Law.

Tanzeh, Ahmad \& Imam Junaris. 2019. "Principal Policy In Developing Islamic Student Characters." Khatulistiwa: Journal of Islamic Studies Vol.9, No.

Wardiono, Kelik. 2016. Paradigma Profetik (Pembaruan Basis Epistemologi Ilmu Hukum). Yogyakarta: Genta Publishing.

Zubair, Anton Bakker \&. 1990. Metodologi Penelitian Filsafat. Yogyakarta: Kanisius. 